\title{
Kelotok (Motorboat) Utilization as the River Transportation in Banjarmasin
}

\author{
Sidharta Adyatma \\ Geography Education Department \\ Faculty of Teacher Training and Education \\ Universitas Lambung Mangkurat \\ Banjarmasin, Indonesia
}

\begin{abstract}
The objective of study is to determine the utilization of Kelotok (motorboat) as the river transportation in Banjarmasin City. The research is conducted in Tanjung Pagar Village, South Banjarmasin Sub-district. This research type is descriptive research through survey. Sample of the research is 364 people. Data analysis uses percentage analysis. The results show that Kelotok is a safety of river transportation to use, although safety equipment such as tires or life jackets is not available. The comfort level is in the middle criteria, because passengers sometimes feel disturbed by the noise and smoke of some Kelotok machines. Kelotok expense very cheap compared to other transportation such as angkot (Transportation Public).
\end{abstract}

Keywords-Kelotok (Motors Boat), River Transportation

\section{INTRODUCTION}

River is fresh water flowing from its source on land to and empties into the sea, lake or other big river. The river is used by the people for various activities, among others, as a source for irrigation or irrigation waterworks and inland water enterprises, power sources for hydropower (PLTA), places for breeding and catching fish, recreation areas, sports venues, the need for water for daily living for the residents who live by the river, such as washing, bathing and cleaning furniture and also as a means of transportation [1]

Rivers have a tremendous role for the development of human conquests around the world by providing fertile areas commonly located in river valleys and as a source of water for the ultimate source of life for human beings. In South Kalimantan the river has a role as a means of transportation to improve mobility and communication between people.

River, lake and ferry transports are part of water transportation facilities. The function of water communications is directed to integrate with road and rail transport systems. The existence of such integration is expected to be a link between rural, inland, border, remote islands and transmigration areas with urban centers.

Transportation is the activity of moving goods and passengers from one place to another. Transport of the river are such as long boat, speed boat, motor boat, or motor boat and motor getek or better known as Kelotok. Factors that affect a person in the choice of transportation are the factors of security, convenience, speed, pleasure, satisfaction and Tariffs or Tariffs. Other factors to consider are ease of access to terminals or docks.

South Kalimantan is a province that has rich natural resource potential and various cultural styles. One of the potential of these natural resources is the number of large and small rivers that flow. The physical condition of the environment generally contributes to the economic activity through the river, so that river transport becomes the dominant and most important factor for traffic [2]. River becomes the center of activity to drive the wheel of economy as trade and traffic [3].

River for the people of South Kalimantan, is the lifeblood of the community in this area. Since the time of the kingdom of Banjar many open the river ports as trading airports. The people of South Kalimantan cannot be separated with the distinctive features of river culture, because the geographical condition itself is a land that is surrounded by river basins, so there is a dub that South Kalimantan is a "city of a thousand rivers". Utilization of the majority river is for the means of transportation, trade, and other necessities of life. One thing to note from this area is the development of people who still embrace the river culture, and has the potential to be made as one of the attractions of interest to the people of South Kalimantan.

Banjarmasin city is one of the cities in South Kalimantan known as "the city of a thousand rivers". The name of the city of a thousand rivers describes the number of rivers contained in the city of Banjarmasin. The river in Banjarmasin city is useful as a source of water for bathing, drinking and washing for people living in the watershed, and used as an alternative route for trade and inter-place transportation.

Based on the results of observation with the community of one urban village in the city of Banjarmasin Tanjung Pagar using land transportation services are fewer than the people who use Kelotok because land transportation available in the Village Tanjung Pagar very little in the appeal Kelotok. Based on the observation of roads in Tanjung Pagar Village is not all paved, narrow and punch, so, people prefer to use Kelotok for daily activities.

Based on community information and observation results in Kelurahan Tanjung Pagar Kelayan is used as transportation 
infrastructure, which is very helpful to the surrounding community in carrying out daily activities. Based on data in Kelurahan Tanjung Pagar people who have Kelotok as many as 52 people and who have land transportation (angkot) is as many as 4 people. Based on observations Kelotok more often pass to take passengers every day in the appeal of land transportation. Kelayan River has a length of $7 \mathrm{~km}$. Tanjung Pagar village is crossed by a $3 \mathrm{~km}$ long river. Kelurahan Tanjung Pagar Kelayan River in Tanjung Pagar Village is crossed 95 times; meanwhile the average land transportation 7 times passes. The existing jetty in Tanjung Pagar Village is as many as 113 docks, while the ground transportation stop is only 1 terminal.

\section{METHOD}

This type of research is descriptive research that aims to describe the utilization of Kelotok in Banjarmasin City. This study uses a powerful approach through a survey to the community in the city of Banjarmasin and supported also with a qualitative approach as it seeks to identify comprehensively about the utilization of Kelotok as a means of transportation in the river.

The subjects of this study are the people residing in Tanjung Pagar Village, South Banjarmasin Subdistrict, totaling 6,032 people. The number of samples of this study is calculated using the Krijtce Morgan table, obtained as many as 364 inhabitants. Determination of sample uses technique of Purposive Sampling. In detail the research sample based on the neighborhood (RT) can be seen in Table 1 below.

TABLE 1. SAMPLE RESEARCH

\begin{tabular}{|c|r|r|}
\hline RT & Total Population & Sample \\
\hline 9 & 825 & 78 \\
11 & 532 & 50 \\
12 & 769 & 73 \\
14 & 1.018 & 96 \\
17 & 326 & 31 \\
18 & 121 & 11 \\
21 & 262 & 25 \\
\hline Amount & $\mathbf{3 . 8 5 3}$ & $\mathbf{3 6 4}$ \\
\hline
\end{tabular}

Variables of this research is the utilization of society using transportation of Kelotok namely security, availability, smoothness, security and Tariffs. Data analysis used quantitative descriptive technique using percentage formula and spread questioner to all samples. All data collected will be entered into tables using the percentage formula [4].

$$
P=\frac{\mathrm{f}}{\mathrm{N}} \times 100 \%
$$

Information:

$\mathrm{P}=$ Percentage $(\%)$

$\mathrm{F}=$ frequency

$\mathrm{N}=$ Respondents' home

\section{RESULT AND DISCUSSION}

The age group of respondents in this study is the age group between 15 years to 54 years. Age between 15 years to 54 years has physical and mental maturity and is a productive age. The distribution of respondents by age or age is presented in Table 2.

TABle 2. Number of ReSPONDENTS by Age GRouP

\begin{tabular}{|c|c|c|r|}
\hline No & Age & $\begin{array}{c}\text { Frequency } \\
(\mathbf{F})\end{array}$ & $\begin{array}{c}\text { Percentage } \\
(\mathbf{\%})\end{array}$ \\
\hline 1 & $15-19$ & 65 & 17.86 \\
2 & $20-24$ & 53 & 14.56 \\
3 & $25-29$ & 31 & 8.52 \\
4 & $30-34$ & 42 & 11.54 \\
5 & $35-39$ & 83 & 22.80 \\
6 & $40-44$ & 37 & 10.16 \\
7 & $45-49$ & 29 & 6.79 \\
8 & $50-54$ & 24 & 7.97 \\
\hline & & & $\mathbf{1 0 0 , 0 0}$ \\
\hline
\end{tabular}

Table 2 shows that most respondents were between the ages of 35-39 years i.e. 83 respondents or $22.80 \%$ and the lowest age of respondents were age between 50-54 years or $7.97 \%$. Meanwhile, when viewed from the level of education, most respondents are elementary school is 83 respondents or $22.80 \%$ and the least is $\mathrm{S} 1$ that is as much as 40 respondents or $10.99 \%$. In detail the level of education respondents can be seen in Table 3.

TABLE 3. NUMBER OF RESPONDENTS BY LEVEL OF EDUCATION

\begin{tabular}{|c|c|c|c|}
\hline No & Level of Education & $\begin{array}{c}\text { Frequency } \\
(\mathrm{F})\end{array}$ & $\begin{array}{c}\text { Percentage } \\
(\%)\end{array}$ \\
\hline 1 & Graduated SD & 83 & 22.80 \\
2 & Graduated SMP & 74 & 20.33 \\
3 & Graduated SMU & 54 & 14,84 \\
4 & Graduated D-2 & 71 & 19.50 \\
5 & Graduated D-3 & 42 & 11.54 \\
6 & Graduated S-1 & 40 & 10.99 \\
\hline \multicolumn{2}{|c|}{ Amount } & 364 & 100,00
\end{tabular}

Work related to the source of income of respondents. The types of respondents' work in this study consisted of Civil Servants (PNS), private employees, traders, drivers, laborers and students. The distribution of respondents by livelihood is presented in Table 4.

TABLE 4. POPULATION BY TYPE OF WORK

\begin{tabular}{|c|c|c|c|}
\hline No & Type of Work & $\begin{array}{c}\text { Frequency } \\
(\mathrm{F})\end{array}$ & $\begin{array}{c}\text { Percentage } \\
(\%)\end{array}$ \\
\hline 1 & Government employees & 84 & 23.08 \\
2 & Private employees & & \\
3 & Merchants & 93 & 25.55 \\
4 & Driver & 97 & 26.65 \\
5 & Labor & 41 & 11.26 \\
6 & Not yet working & 43 & 11.81 \\
& & 6 & 1.65 \\
\hline
\end{tabular}

Table 4 above shows that most of the respondents work as traders i.e. 97 respondents or $26.65 \%$, respondents who have not worked are 6 respondents or $1.65 \%$. This means that the level of education affect the work of respondents.

The results of respondents, who have been edited and tabulated, then made a description based on each indicator of security, availability, fluency, comfort and availability. Here is described more in depth challenging research results.

\section{A. Security}

Security in the use of Kelotok is important for the user. People use Kelotok as a means of transportation in the river 
because they feel safe, 352 respondents or $96.70 \%$ say the Kelotok they use is not prone to leak, meaning that respondents feel safe in the use of Kelotok as a means of transportation in the river. Furthermore, the respondents explained that the Kelotok they were traveling on did not stop or keep the road slowly every down or up the passengers, although it can be said unsafe but the respondents said it was used and felt safe, because the river condition is not wavy.

The existence of safety equipment for passengers is important for the safety of passengers. Known as many as 364 respondents or $100 \%$ answered the unavailability of tire savior. Rescue tires are unavailable because they think rare crashes in the river. Judging from the capacity of passengers in loading passengers has affected the safety of passengers. A total of 211 respondents or $57.97 \%$ said the Kelotok they were riding often carry passengers over capacity. That is, when viewed from the safety equipment and the capacity of passengers Kelotok unsafe.

\section{B. Availability of Kelotok}

The length of time waiting to ride Kelotok associated with smoothness in its use. A long time to wait can lead to disruption of community activities that want to ride Kelotok. Respondents said waiting time Kelotok $\leq 5$ minutes, and the longest 5-10 minutes. This means that the availability of Kelotok in good condition, due to the number of Kelotok that exist in the city of Banjarmasin in quite a lot.

\section{Smoothness}

Kelotok traffic often becomes important in the smooth use of Kelotok services. Respondents said the traffic of the Kelotok was smooth. Traffic Kelotok smoothly because the road Kelotok the traffic is not too much and the width of the river is enough for Kelotok traffic. The departure of the Kelotok does not have a schedule because the departure of Kelotok in accordance with the wishes of the driver or driver Kelotok.

\section{Convenience}

Convenience in using Kelotok to get to the destination is very important for Kelotok users. This can increase or attract more transit users. The state of Kelotok in general according to the respondent is clean. In detail the Kelotok condition according to the respondents can be seen in Table 5 .

\section{TABLE 5. CLEANLINESS KELOTOK}

\begin{tabular}{|l|c|c|}
\hline $\begin{array}{c}\text { Respondents } \\
\text { answer }\end{array}$ & $\begin{array}{c}\text { Frequency } \\
(\mathbf{F})\end{array}$ & $\begin{array}{c}\text { Percentage } \\
(\mathbf{\%})\end{array}$ \\
\hline Very clean & 90 & 24,72 \\
Clean & 105 & 28,85 \\
Fairly clean & 91 & 25 \\
Not clean & 78 & 21,43 \\
\hline \multicolumn{1}{|c|}{ Total } & $\mathbf{3 6 4}$ & $\mathbf{1 0 0 , 0 0}$ \\
\hline
\end{tabular}

Table 5 above shows that the Kelotok state is clean. Another thing that relates to the comfort of passengers is the wave of the river is not large, but when fellow Kelotok passengers make the less comfortable, Kelotok who walk to be swayed to make passengers afraid.
Traffic conditions in the river affect the comfort of passengers. According to the respondents the traffic orders Kelotok very good because there is never a Kelotok that violates the rules or disturb other Kelotok trip. Smoke generated Kelotok can affect the comfort of passengers. The results showed that respondents did not feel disturbed by the smoke Kelotok, but there are some who feel disturbed, because there is some Kelotok excessive smoke. Noisy engine noises also make passenger's Kelotok become uncomfortable.

\section{E. Tariffs}

Tariffs of Kelotok either long distance or close sometimes there are not the same and there is also the same, uniformity of Kelotok is one of the reasons people want to use Kelotok in everyday activities. The results showed that the Tariffs of uniform or same Kelotok both close and far distance. Uniform Tariffss affect the community to use Kelotok. Respondents said that the Tariffs of Kelotok cheaper than angkot, because Kelotok more simple than the angkot (public transportationt).

\section{CONCLUSION}

Based on the results of research that has been done in Kelurahan Tanjung Pagar District Banjarmasin Selatan can be summed up as follows:

1. Kelotok is a means of transportation of rivers in the city of Banjarmasin is safe, because it never leaked, but less secure because safety devices such as rescue tires are not available, and safety buoy is available but not in accordance with the number of passengers.

2. Availability of Kelotok in good condition, because the number of Kelotok that exist in the city of Banjarmasin in considerable amount. Wait time Kelotok $\leq 5$ minutes, and maximum 5-10 minutes.

3. Departure Kelotok not have a schedule because the departure Kelotok in accordance with the wishes of drivers or driver Kelotok.

4. Condition Kelotok in clean, so penumopang feel comfortable, but passenger feel uncomfortable with smoke and noise of noisy machine.

5. Tariffs Kelotok very cheap when compared to other transportation such as angkot, so they prefer Kelotok as their means of transportation.

Based on the results of the questionnaire it can be concluded generally that Kelotok is still needed, the factors causing the respondents need Kelotok transportation is safe because it does not often leak and water does not often enter when exposed to waves, Kelotok transportation is available because waiting time Kelotok not long, transportation Kelotok smoothly because the traffic Kelotok smoothly and the rubbish drift in the river does not interfere with the smoothness of the road Kelotok, using the transportation tools Kelotok convenient because garbage drifting in the river does not interfere with the comfort of respondents, smoke and machine Kelotok not disturb the respondents, and the Tariffs is cheap because the Tariffs of uniform Kelotok either close or far, the 
same mileage Tariffs cheaper than the angkot (public transportationt).

\section{REFERENCES}

[1] Syarifudin, Banjar Boat, Special Publisher Series State Museum Mangkurat, 1990.
[2] A. Nuralang, Rivers in Kalimantan, Bandung: Alfa, 2004.

[3] Sunarningsih, Rivers in Kalimantan, Bandung: Alfa, 2004

[4] A. Sudijono, Introduction to Education Statistics, Jakarta: PT. Radja Grafindo Persada, 2003. 